\title{
Characteristics of Carcass Traits and Meat Quality of Broiler Chickens Reared under Conventional and Free-range Systems
}

\author{
Peymaneh Davoodi and Alireza Ehsani* \\ Department of Animal Science, Tarbiat Modares University, Tehran, PO Box 14115-336, Iran. \\ *Corresponding author's E-mail: alireza.ehsani@modares.ac.ir ; ORCID: 0000-0001-6933-3469
}

Received: 01 Nov. 2020

Accepted: 14 Dec. 2020

\begin{abstract}
Alternative chicken production systems have become popular in recent years due to animal welfare criteria and consumer's perceptions. General beliefs express that the meat quality of chicken reared under free-range systems is better than that of chickens under conventional production conditions. The aim of this study was to compare the meat quality and carcass traits of chickens raised in conventional and free-range systems. Either conventional or free-range systems used meat-type Hubbard JA57 birds with a slaughter age of approximately 78 days. For assessing carcass traits and meat quality, six male chickens were selected from each system. The meat quality parameters, $\mathrm{pH}$ at 45 minutes, ultimate $\mathrm{pH}$, color coordinates, drip loss, cooking loss, and water-holding capacity were measured. Furthermore, proximate parameters, such as crude protein, total fat, and crude ash were determined. There were no significant differences in main carcass yield and breast muscles between chickens reared in two systems, however, color values dramatically were influenced by rearing systems. Breast muscle samples from birds reared under the conventional system had a smaller hue angle and saturation value than those from the free-range birds. Moreover, the drip loss parameter was significantly higher in free-range chickens. The ash and protein contents of breast muscles were similar although raw breast meat from free-range birds had significantly lower fat content. The results prove that a free-range rearing system can modify the appearance, color values, and fat content of chicken meat and it can be a part of the interests of meat production consumers.
\end{abstract}

Keywords: Broiler chickens, Free-range, Hubbard JA57, Intensive rearing system, Meat quality

\section{INTRODUCTION}

Chickens were primarily raised on family farms outdoor until around the 1950s (Alvarado et al., 2005). Since then the remarkable growth of chicken meat production commenced when the modern poultry industry began. This has led to developing intensive rearing systems, ensuring highest effectiveness and profitability of production (Bogosavljevi-Boskovic et al., 2012). However, intensive systems and rapid growth can cause animal stress, resulting in undesirable physiological and behavioral responses which lead to poor performance and meat quality (Xing et al., 2019) and occurrence of idiopathic myopathies, white striping, wooden breast, as well as pale, soft and exudative (PSE)-like meat (Ishamri and SeonTea, 2017). In contrast, free-range system can decrease stress conditions and allow better chicken welfare without causing any environmental confinement on broilers (Santos et al., 2005; da Silva et al., 2017). The poultry meat quality, in general, is an extremely complex concept that can be evaluated from different aspects because it is dependent on numerous factors, including genotype, sex, age, diet, density, environment and also rearing system (Berg, 2001; Brown et al., 2008; Miele, 2011; da Silva et al., 2017). In this respect, over the last decades, poultry meat production has paid particular attention to animal welfare, high-quality food safety standards, and different rearing systems. So, the competitiveness in this market has been radically changed into equally both price and quality competitiveness (Berg, 2001; Yeung and Morris, 2001; Bogosavljevic-Boskovic et al., 2010; Saleh et al., 2015).

From the prevailing viewpoint, broilers should have not only high slaughter yields and desirable carcass conformation scores, but also proper aesthetic, nutritional, and healthy characteristics. Hereupon, the chemical composition of chicken meat is another essential factor of broiler meat quality (Berg, 2001; Yeung and Morris, 2001; Castellini et al., 2008; Wang et al., 2009; Miele, 2011; Saleh et al., 2015; Srednicka-Tober et al., 2016). According to previous studies, broilers that had outdoor access showed better meat quality considering chemical 
composition and healthy characteristics of produced meat (Berg, 2001; Castellini et al., 2008; Miele, 2011; Saleh et al., 2015; Srednicka-Tober et al., 2016). Castellini et al. (2002) and Lin et al. (2014) also claimed that chemical contents in the chicken meat produced in free-range were better than those from other conventional systems, also meat sensory scores and overall acceptability in the freerange group were higher than those in other systems. In addition, high protein content, and low fat in meat of freerange chickens offers a healthier diet choice (Lin et al., 2014). Given that the consequence of rearing systems can differ by fattening length, the density of the flock, time to access free range, climatic factors, seasons and breeds, the results reported in previous studies are often quite variable (Bogosavljevi-Boskovic et al., 2012; Srednicka-Tober et al., 2016). Some authors have reported no significant effect of rearing system on carcass yields and meat quality traits but others have obtained statistically significant differences (Wang et al., 2009). Therefore, the objective of the current study was to evaluate the growth performance, carcass characteristics, and meat quality of Hubbard JA57 strain (known for free-range rearing) in both conventional and free-range systems in Iran condition.

\section{MATERIALS AND METHODS}

\section{Ethics approval}

The Ethics Committee on the Use of Animals of Tarbiat Modares University, Iran approved all the experiments and protocols used in this study (14-67626). All experimental protocols were applied in accordance with relevant legislation and recommendations by this committee.

\section{Experimental schedule and sample collection}

This trial was carried out at the Poultry Experimental Farm in Tarbiat Modares University, Iran from September to November 2017. The test material used in this study included a total of 82 fertile eggs of slow-growing Hubbard JA57 strain imported from Denmark. The eggs were placed in an incubator (Victoria Como, Italy) with the broad end pointing upwards and proper temperature and humidity. At the end of 18 days of incubation, the eggs were transferred into individual pedigree hatch bags sewn with a net fabric in order that chicks could be traced back to their initial egg weights. The hatch was pulled at day 21.5 with hatchability of $91 \%$, then all 74 day-old chicks generated were identified with left leg tags using plastic cable ties and housed in a standard conventional system until the end of week 5 and then divided randomly into two groups each with 36 birds, one was reared in the same house and the other was transferred to the free-range system until the end of the rearing period of 11 weeks. Birds were provided with the same starter and finisher diets (Table 1), formulated based on the chemical composition of ingredients and broiler nutritional requirements according to NRC (NRC, 1994). The summary of the rearing systems conditions is given in Table 2. At the end of the rearing period of 11 weeks, 12 male broilers (6 from each rearing system) with a target weight range of 3.2 to $3.5 \mathrm{~kg}$ were randomly chosen to provide materials for analysis and sent to the chicken slaughterhouse related to the Department of Animal Sciences of Tarbiat Modares University, Iran to assess carcass characteristics and meat quality. After fasting for 12 hours before slaughter, all birds were weighed individually, slaughtered, and processed using standard commercial practices. All of them were used for physical, chemical, raw and cooked product analyses. The organ weights (liver, spleen, gizzard, heart, bursa of Fabricius) were recorded.

Table 1. Ingredients of starter and finisher diets and Dry matter based proximate chemical composition of diets.

\begin{tabular}{|c|c|c|}
\hline Item & $\begin{array}{c}\text { Starter } \\
(1-4 \text { weeks })\end{array}$ & $\begin{array}{c}\text { Finisher } \\
\text { (5-11 weeks) }\end{array}$ \\
\hline \multicolumn{3}{|l|}{ Ingredient } \\
\hline Maize & 59.78 & 66.00 \\
\hline Soybean meal & 28.52 & 22.00 \\
\hline Soybean oil & 4.50 & 3.80 \\
\hline Wheat bran & 4.56 & 5.92 \\
\hline Dicalcium phosphate & 1.05 & 0.60 \\
\hline Limestone powder & 0.90 & 1.05 \\
\hline Mineral and Vitamin Mix & 0.34 & 0.34 \\
\hline Salt & 0.10 & 0.10 \\
\hline Lysine & 0.10 & 0.13 \\
\hline Methionine & 0.15 & 0.06 \\
\hline Threonine & 0.00 & 0.06 \\
\hline \multicolumn{3}{|l|}{ Chemical composition } \\
\hline $\begin{array}{l}\text { Metabolizable energy } \\
(\mathrm{kcal} / \mathrm{kg})\end{array}$ & 3100 & 3150 \\
\hline Crude protein $(\%)$ & 23.00 & 20.00 \\
\hline Crude fiber $(\%)$ & 2.44 & 2.60 \\
\hline Ether extract (\%) & 7.16 & 6.20 \\
\hline Lysine (\%) & 1.12 & 1.00 \\
\hline Methionine (\%) & 0.50 & 0.39 \\
\hline Calcium (\%) & 1.00 & 0.90 \\
\hline
\end{tabular}


Table 2. Summary of rearing conditions for chickens raised under two different systems.

\begin{tabular}{lll}
\hline Items & $\begin{array}{l}\text { Conventional rearing } \\
\text { system }\end{array}$ & $\begin{array}{l}\text { Free-range rearing } \\
\text { system }\end{array}$ \\
\hline Outdoor access & No access & Access after week 5 \\
\hline Diet & $\begin{array}{l}\text { Ad libitum regular diet } \\
\text { with no animal } \\
\text { ingredient }\end{array}$ & $\begin{array}{l}\text { Ad libitum regular } \\
\text { diet with no animal } \\
\text { ingredient + access } \\
\text { to pasture }\end{array}$ \\
\hline Water & Ad libitum & Ad libitum \\
\hline Vaccine program & $\begin{array}{l}\text { Regular vaccination } \\
\text { against Newcastle }\end{array}$ & $\begin{array}{l}\text { Regular vaccination } \\
\text { against Newcastle }\end{array}$ \\
\hline Antibiotic & No antibiotic & No antibiotic \\
\hline $\begin{array}{l}\text { Slaughter age } \\
\text { (day) }\end{array}$ & 78 & 78 \\
\hline
\end{tabular}

\section{Measurements and evaluations}

The meat quality variables, carcass component yield, initial and ultimate $\mathrm{pH}$, color coordinates (Lightness, $\mathrm{L}^{*}$; redness, $a^{*}$; yellowness, $b^{*}$ ), Hue angle, saturation, drip loss, and water-holding capacity were measured. Also, cooked breast samples were evaluated for cooking yield (Mikulski et al., 2011).

\section{Carcass component yield}

The carcass weight was obtained after removing the head, neck, and shanks. Then, the main commercial segments (e.g., warm carcass, breast, and leg) and marginal parts (e.g., wings, abdominal fat, spleen, testicles, heart, and gallbladder) were weighed. Finally, the values were expressed as a percentage of carcass weight (Santos et al., 2005; Comert et al., 2016).

\section{pH}

The initial $\mathrm{pH}$ (45 min after slaughtering) and ultimate $\mathrm{pH}$ ( $\mathrm{pH}$ in $24 \mathrm{~h}$ after slaughtering) were measured on raw homogenized breast muscles of six chickens from each group with three replications, in the same procedure. Approximately $2.5 \mathrm{~g}$ of meat was removed from the center of each pectoral major muscle, minced by mortar and pestle, and suspended in $25 \mathrm{~mL}$ distilled water then centrifuged for $5 \mathrm{~min}$ at $6000 \mathrm{rpm}$. Measurement of $\mathrm{pH}$ was performed using a digital $\mathrm{pH}$ meter equipped with a sensitive electrode, the device was calibrated before measurement at $\mathrm{pH} 4.0$ and 7.0 buffer solutions (Choo et al., 2014).

\section{Cooking loss}

Cooking loss was determined by weighing meat before and after cooking. Meats were enveloped in an aluminum foil and cooked in an electric oven at $100{ }^{\circ} \mathrm{C}$ for $15 \mathrm{~min}$, then samples were removed from the oven and left to cool at room temperature (Lin et al., 2014).

\section{Drip loss}

Drip loss was measured by keeping samples suspended in covered plastic bags on plastic racks for $48 \mathrm{~h}$ at $2{ }^{\circ} \mathrm{C}$ and calculated as a percentage of weight loss during storage (Funaro et al., 2014).

\section{Water-holding capacity}

Water-holding capacity was determined by the filter paper press method to obtain expressible meat juice. A $1000 \mathrm{mg}$ raw meat sample was placed between several pieces of filter paper with $11 \mathrm{~cm}$ diameter and pressed for $5 \mathrm{~min}$. Expressed juice of meat was defined as the loss in weight after pressing and expressed as a percentage of the initial weight of the raw meat sample (Wierbicki and Deatherage, 1958; Lee, 1995).

\section{Color}

The color profile of lightness, $\mathrm{L}^{*}$; redness, $\mathrm{a}^{*}$; yellowness, $b^{*}$ was measured by a reflectance colorimeter (ColorFlex EZ Spectrophotometer, USA) in triplicate on raw breast meat. The device was calibrated with black and white standards before meat color determination. Hue angle and saturation index were measured using formulas

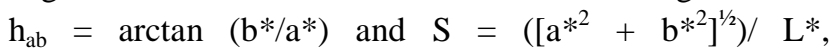
respectively (da Silva et al., 2017).

\section{Proximate analysis}

Protein, fat, and ash content of raw breast were each independently measured with three replications from each of 6 broilers from free-range and 6 broilers from standard rearing system. Samples for proximate analysis were frozen until analyzed at the laboratory of the Animal Science Faculty of Tarbiat Modares University. Protein, fat, and ash content was measured following the AOAC methodology (Lee, 1995).

\section{Statistical analysis}

The $\mathrm{R}$ 4.0.2 software was used for statistical analysis. Pairwise treatment differences between carcass traits obtained from two different rearing system were determined with the Student t-test and any differences were considered significant at $p<0.05$, for this reason, data were summarized as mean \pm standard deviation and analyzed by one-way analysis of variance taking the rearing system as the main effect.

\section{RESULTS}

The comparison of carcass traits between the two rearing systems is reported in Table 3. There were no significant effects of rearing systems on the main carcass parameters measured. The results of physical and chemical meat characteristics comparison between conventional and the 
free-range system are presented in Table 4. The initial $\mathrm{pH}$ of the breast meat from free-range broilers was slightly lower than conventional even though the ultimate $\mathrm{pH}$ of the breast meat became higher in free-range than conventional birds. These differences were not statistically significant but the difference of initial and ultimate $\mathrm{pH}$ values in free-range birds showed significant change $(\mathrm{p}=$ $0.004)$.

Table 3. Carcass characteristics of chickens reared under conventional and free-range systems.

\begin{tabular}{|c|c|c|c|c|}
\hline Trait & Conventional system & Free-range system & t statistics & p-value \\
\hline Live Weight (g) & 3548.33 & 3371.67 & -1.279 & 0.229 \\
\hline Carcass Weight (g) & 2770.83 & 2560.00 & -1.722 & 0.115 \\
\hline Drop Carcass (g) & 777.50 & 811.67 & 0.758 & 0.465 \\
\hline Tight (\%) & 25.56 & 25.31 & -0.424 & 0.680 \\
\hline Breast (\%) & 26.87 & 27.29 & 0.509 & 0.621 \\
\hline Wings (\%) & 11.63 & 10.97 & -1.353 & 0.205 \\
\hline Legs $(\%)$ & 4.57 & 4.74 & 1.197 & 0.258 \\
\hline Liver $(\%)$ & 2.10 & 2.22 & 0.899 & 0.389 \\
\hline Abdominal fat (\%) & 2.50 & 2.53 & 0.114 & 0.911 \\
\hline Gizzard (\%) & 1.46 & 2.45 & 2.002 & 0.096 \\
\hline Testicle (\%) & 0.15 & 0.07 & -2.314 & 0.061 \\
\hline Burse $(\%)$ & 0.13 & 0.18 & 1.299 & 0.222 \\
\hline Gallbladder (\%) & 0.15 & 0.10 & -1.908 & 0.085 \\
\hline Spleen $(\%)$ & 0.19 & 0.22 & 1.360 & 0.203 \\
\hline Heart $(\%)$ & 0.63 & 0.60 & -1.244 & 0.241 \\
\hline
\end{tabular}

Each group contained 36 chickens. *Statistically significant at $\mathrm{p}<0.05$

Table 4. Chicken carcass quality traits in conventional and free-range rearing systems.

\begin{tabular}{lcccc}
\hline Meat quality traits & Conventional system & Free-range system & t-statistics & p-value \\
\hline pH measures & & & & \\
Initial pH & $5.81 \pm 0.11$ & $5.78 \pm 0.15$ & -0.379 & 0.713 \\
Ultimate pH & $5.77 \pm 0.14$ & $5.83 \pm 0.09$ & 1.450 & 0.178 \\
pH difference & $-0.04 \pm 0.10$ & $0.05 \pm 0.10$ & 3.727 & $0.004^{*}$ \\
Meat quality metrics & & & \\
$\quad$ Cooking loss & $29.33 \pm 2.45$ & $28.10 \pm 1.70$ & -1.259 & 0.237 \\
Drip loss & $3.24 \pm 1.22$ & $3.70 \pm 1.60$ & 2.384 & $0.038^{*}$ \\
Water holding capacity & $53.03 \pm 2.32$ & $55.26 \pm 1.80$ & 1.92 & 0.08 \\
Color parameters & & & & $0.000^{*}$ \\
Lightness & $59.92 \pm 0.33$ & $52.00 \pm 2.70$ & -7.008 & $0.002^{*}$ \\
Redness & $7.29 \pm 1.79$ & $3.40 \pm 1.30$ & -4.309 & $0.034^{*}$ \\
Yellowness & $11.01 \pm 2.04$ & $13.20 \pm 0.90$ & 2.461 & $0.002^{*}$ \\
Hue angle & $56.40 \pm 10.03$ & $75.60 \pm 4.80$ & 4.233 & $0.001^{*}$ \\
$\quad$ Saturation & $13.40 \pm 1.29$ & $13.70 \pm 1.00$ & 4.902 & \\
\hline
\end{tabular}

Data are expressed as mean \pm standard deviation. Each group contained six chickens. *Statistically significant at $\mathrm{p}<0.05$. 
Table 5. Proximate analysis of raw breast meat from conventional and free-range broilers.

\begin{tabular}{lcrrr}
\hline Proximate analysis & Conventional system & Free-range system & t-statistics & p-value \\
\hline Protein, \% & $23.85 \pm 0.41$ & $24.20 \pm 0.54$ & 1.23 \\
Fat, \% & $4.01 \pm 0.40$ & $3.18 \pm 0.40$ & -3.57 \\
Ash, \% & $3.03 \pm 0.21$ & $3.05 \pm 0.28$ & -0.12 & $0.005^{*}$ \\
\hline
\end{tabular}

Data are expressed as mean \pm standard deviation. Each group contained six chickens. *Statistically significant at $\mathrm{p}<0.05$

The effect of the two rearing systems on meat quality did not represent a significant difference in terms of the cooking loss and water holding capacity parameters, however, the drip loss parameter was affected by rearing systems significantly $(p=0.038)$. All the color coordinates $L^{*}, a^{*}, b^{*}$, hue angle, and saturation value also showed extremely significant differences between the rearing systems. Breast muscle from free-range birds revealed significantly lower $\mathrm{L}^{*}$ and $\mathrm{a}^{*}$ values making it paler in comparison to conventional breast muscle. The smallest difference was seen in the $b^{*}$ coordinate with the breast muscle from the free-range birds which was significantly higher than conventionally reared birds, so breast meat in free-range was more yellow $(p=0.03)$ than conventional.

The result of the proximate analysis of the raw breast meat produced from chickens reared under conventional and the free-range system is reported in Table 5. Raw breast meat from free-range birds had significantly $(\mathrm{p}=$ 0.005 ) lower fat content in comparison to broilers reared conventional system, however, no significant differences ( $p>0.05$ ) was observed for protein and ash content of the raw breast meat.

\section{DISCUSSION}

A growing knowledge of human health, food safety, and animal welfare interests have led to the great transformation in animal rearing systems and particularly free-range product markets all over the world. Chicken meat produced in alternative systems, such as free-range or organic, are part of this orientation. It is specified that slaughtering age, genetic breeds (fast and slow-growing), physical activity, and pasture intake are key factors in chicken meat quality.

In this research, no significant differences were observed in yield of carcass parts. The result has no consistency with the findings of Mikulski et al. (2011) who reported the significant influence of rearing system on carcass yields. Several studies also reported that body weight, body weight gain, and the proportion of breast meat of birds from the free-range system were significantly lower than of those reared in indoor floor system (Grashorn and Serini, 2006; Dou et al., 2009; Wang et al., 2009). Conversely, some other researchers have found that free-range chickens had the higher live weight, breast, and thigh-drumstick weights compared to the conventional system (Alvarado et al., 2005; Santos et al., 2005; Połtowicz and Doktor, 2011; Lin et al., 2014; Comert et al., 2016) and also there are some other results reported by different researchers that were consistent with findings of the current study as they claimed that most of the carcass yield, especially body weight, did not show significant changes (Cheng et al., 2008; Chen et al., 2013; Fu et al., 2015).

The meat quality attributes including color values, $\mathrm{pH}$ measures, and water holding capacity were evaluated in this experiment because these parameters can have important effects on the characteristics of fresh chicken meat at the point of sale (Kim et al., 2020).

In the present study, the initial and ultimate $\mathrm{pH}$ of breast meat were slightly affected by two rearing systems but the changes were not significant and this finding was consistent with the results of many studies (Cheng et al., 2008; Husak et al., 2008; Ponte et al., 2008; Wang et al., 2009; Mikulski et al., 2011; Li et al., 2017). Although the initial and ultimate $\mathrm{pH}$ values were not significantly different between the two rearing systems, their variation obviously showed a different pattern that could be deduced why some studies have concluded that meat from broilers reared in the free-range system had lower shelflife stability compared with conventionally reared broiler meat (Alvarado et al., 2005; Husak et al., 2008; Funaro et al., 2014). Because $\mathrm{pH}$, microorganism content, and oxidation are intra-dependent factors and $\mathrm{pH}$ alteration during storage can be resulted by proteolytic degradation or fat oxidation which is decreases shelf-life of meat (Kim et al., 2020). This notable different pattern in $\mathrm{pH}$ change in breast meat of free-range birds might be the result of intensive physical activity and more pre-slaughter stress in comparison to the conventional broilers (da Silva et al., 2017; Kim et al., 2020). Pre-slaughter stress and physical activity in free-range chicken may lead to the range of 
chemical changes based on the conversion of ATP to ADP and also anaerobic glycolysis of glycogen storage in muscles decreases $\mathrm{pH}$ due to lactic and pyruvic acid production so finally it can change the meat acidity during the rigor mortis.

The influence of the two studied rearing systems on meat quality did not reveal a significant difference in the cooking loss and water holding capacity parameters, although, drip loss parameter was affected by rearing systems significantly. The result of water holding capacity concurs with similar studies in comparing breeding methods (Castellini et al., 2002; Cheng et al., 2008; Dou et al., 2009; Wang et al., 2009; Stadig et al., 2016; Li et al., 2017). Water holding capacity is an important attribute of meat quality, if water holding capacity is poor, meat and meat products will lack juiciness. As slow-growing chickens are better suited to the free-range system (Castellini et al., 2008; Kingori et al., 2010; BogosavljeviBoskovic et al., 2012), but Fanatico et al. (2007) claimed that slow-growing birds had weaker water-holding capacity but their meat is more tender than the fastgrowing birds.

The absence of significant differences in the carcass yield and other studied traits between two different systems are may be due to short rearing period with outdoor access. An experiment was conducted to evaluate the effect of free-range days on growth performance, carcass yield, and meat quality; and it was reported that increasing free-range length advantageously affects breast yield, but decreases thigh, and foot yields as well as the water-holding capacity of the thigh. No evidence was found that free-range days can change growth performance and meat quality (except water holding capacity) (Tong et al., 2014).

It can be demonstrated that free-range rearing system can modify the color values in chicken meat as the findings showed the breast meat from free-range broilers had higher yellow color and much lower red color than another rearing system (Brown et al., 2008; Połtowicz and Doktor, 2011; Funaro et al., 2014; da Silva et al., 2017). Of course, it should not be ignored that there were some peculiarities in results reported by authors about meat color values in comparing two standard and free-range meat yield.

According to the present result, raw breast meat from free-range birds had significantly lower fat content in comparison to conventional broilers, which could be important to consumers concerned with fat intake. The obtained results in previous studies suggested that the freerange rearing system was more favorable than the conventional system, as it resulted in significantly higher protein content and a lower fat content of chicken meat (Bogosavljevi-Boskovic et al., 2012) however, no significant differences were observed for protein and ash content of the raw breast in the present study.

\section{CONCLUSION}

Although the quantitative carcass traits showed less significant differences between the two groups, some main qualitative traits including apparent characteristics such as all color coordinates and drip loss were significantly affected by the free-range system. Moreover, fat percentage of raw breast meat was significantly lower in the free-range production system, therefore, it could be healthier. Accordingly, no significant differences in the amount of meat produced in two rearing systems showed that the conventional production system in the poultry industry can be successfully replaced by alternative systems such as free-range without production loss. Also, the different chemical composition of meat in the freerange system may become more attractive in terms of increasing healthy food demand in the world industry. Ultimately, further studies are suggested to investigate consumer preferences, especially in terms of sensory evaluation of meat from the two production systems.

\section{DECLARATIONS}

\section{Competing interests}

We certify that there is no conflict of interest with any financial organization regarding the aspects discussed in the manuscript.

\section{Authors' contributions}

Alireza Ehsani designed the experiments, guided the research team, and edited the final draft of the manuscript. Peymaneh Davoodi performed field and lab researches, analyzed the data, and wrote the paper. Finally, all authors read and approved the final manuscript.

\section{REFERENCES}

Alvarado CZ, Wenger E, and O-Keefe SF (2005). Consumer perceptions of meat quality and shelf-life in commercially raised broilers compared to organic free range broilers. Proceedings of the XVII European Symposium on the Quality of Poultry Meat, Doorwerth, Netherlands, pp. 257261. Available at: https://www.cabi.org/Uploads/animalscience/worlds-poultry-science-association/WPSA-thenetherlands-2005/25.pdf 
Berg C (2001). Health and welfare in organic poultry production. Acta Veterinaria Scandinavica Supplementum, 95: 37-45. DOI: https://www.doi.org /10.1186/1751-0147-43-S1-S37

Bogosavljevi-Boskovic S, Rakonjac S, DoskoviĆ V, and PetroviĆ MD (2012). Broiler rearing systems: A review of major fattening results and meat quality traits. World's Poultry Science Journal, 68(2): 217-228. Available at: https://www.cambridge.org/core/article/broiler-rearingsystems-a-review-of-major-fattening-results-and-meatquality-traits/9F9B98C9AFA0601C2DFA1EA4EF328962

Bogosavljevic-Boskovic S, Pavlovski ZP, Etrovic MD, Doskovic V, and Rakonjac S (2010). Broiler meat quality: Proteins and lipids of muscle tissue. African Journal of Biotechnology, 9(54): 9177-9182. DOI: https://www.doi.org /10.5897/AJB.9000089

Brown SN, Nute GR, Baker A, Hughes SI, and Warriss PD (2008). Aspects of meat and eating quality of broiler chickens reared under standard, maize-fed, free-range or organic systems. British Poultry Science, 49(2): 118-124. DOI: https://www.doi.org /10.1080/00071660801938833

Castellini C, Berri C, Le Bihan-Duval E, and Martino G (2008). Qualitative attributes and consumer perception of organic and free-range poultry meat. World's Poultry Science Journal, 64(4): 500-512. Available at: https://www.cambridge.org/core/article/qualitative-attributes-andconsumer-perception-of-organic-and-freerange-poultrymeat/C17F5D0B7D747DC2578B1B0672F4DFEE

Castellini C, Mugnai C, and Dal Bosco A (2002). Effect of organic production system on broiler carcass and meat quality. Meat Science, 60(3): 219-225. Available at: http://www.sciencedirect.com/science/article/pii/S03091740 $\underline{01001243}$

Chen X, Jiang W, Tan HZ, Xu GF, Zhang XB, Wei S, and Wang XQ (2013). Effects of outdoor access on growth performance, carcass composition, and meat characteristics of broiler chickens. Poultry Science, 92(2): 435-443. DOI: http://www.dx.doi.org/10.3382/ps.2012-02360

Cheng FY, Huang CW, Wan TC, Liu YT, Lin LC, and Luo Chyr CY (2008). Effects of free-range farming on carcass and meat qualities of black-feathered Taiwan native chicken. Asian-Australas Journal of Animal Science, 21(8): 12011206. DOI: https://www.doi.org/10.5713/ajas.2008.80080

Choo YK, Kwon HJ, Oh ST, Um JS, and Kim BG (2014). Comparison of growth performance, carcass characteristics and meat quality of Korean local chickens and silky fowl. Asian-Australas Journal of Animal Science, 27(3): 398-405. DOI: https://www.doi.org/10.5713/ajas.2013.13638

Comert M, Sayan Y, Kirkpinar F, Bayraktar OH, and Mert S (2016). Comparison of carcass characteristics, meat quality, and blood parameters of slow and fast grown female broiler chickens raised in organic or conventional production system. Asian-Australas Journal of Animal Science, 29(7): 987-997. DOI: https://www.doi.org /10.5713/ajas.15.0812

National Research Council (NRC) (1994). Nutrient requirements of poultry: Ninth revised edition, 1994. Washington, DC: The National Academies Press, DOI: https://www.doi.org/10.17226/2114

da Silva DCF, de Arruda AMV, and Goncalves AA (2017). Quality characteristics of broiler chicken meat from freerange and industrial poultry system for the consumers. Journal of Food Science and Technology, 54(7): 1818-1826.
Available

at: https://www.link.springer.com/article/10.1007/s13197-017$\underline{2612-\mathrm{x}}$

Dou TC, Shi SR, Sun HJ, and Wang KH (2009). Growth rate, carcass traits and meat quality of slow-growing chicken grown according to three raising systems. Animal Science Papers and Reports, 27(4): 361-369. Available at: http://agro.icm.edu.pl/agro/element/bwmeta1.element.agro6e21f956-2203-451e-86c3-fd03229a6bab

Fanatico AC, Pillai PB, Emmert JL, and Owens CM (2007). Meat quality of slow- and fast-growing chicken genotypes fed low-nutrient or standard diets and raised indoors or with outdoor access. Poultry Science, 86(10): 2245-2255. DOI: http://www.dx.doi.org/10.1093/ps/86.10.2245

Fu D, Zhang D, Xu G, Li K, and Wang Q (2015). Effects of different rearing systems on meat production traits and meat fiber microstructure of Beijing-you chicken. Animal Science Journal, 86(7): 729-735. DOI: https://www.doi.org $\underline{10.1111 / \text { asj. } 12347}$

Funaro A, Cardenia V, Petracci M, Rimini S, and RodriguezEstrada MT (2014). Comparison of meat quality characteristics and oxidative stability between conventional and free-range chickens. Poultry Science, 93(6): 1511-1522. DOI: https://www.doi.org /10.1111/asj.12347

Grashorn MA, and Serini C (2006). Quality of chicken meat from conventional and organic production. Conference Proceed. Available at: EPC 2006 - 12th European Poultry Conference, Verona, Italy, 10-14 September, 2006 pp.paper $\underline{67 \text { ref. } 6}$

Husak RL, Sebranek JG, and Bregendahl K (2008). A survey of commercially available broilers marketed as organic, freerange, and conventional broilers for cooked meat yields, meat composition, and relative value. Poultry Science, 87(11): 2367-2376. DOI: http://www.dx.doi.org/10.3382/ps.2007-00294

Ishamri I, and Seon-Tea T (2017). Poultry meat quality in relation to muscle growth and muscle fiber characteristics. Korean Journal for Food Science of Animal Resources, 37(6): 873-883. Available at: https://www.ncbi.nlm.nih.gov/pubmed/29725209

Kim HJ, Kim HJ, Jeon J, Nam KC, and Shim KS (2020). Comparison of the quality characteristics of chicken breast meat from conventional and animal welfare farms under refrigerated storage. Poultry Science, 99(3): 1788-1796. Available

at: http://www.sciencedirect.com/science/article/pii/S00325791 19579202

Kingori AM, Wachira AM, and Tuitoek JK (2010). Indigenous chicken production in Kenya: A review. International Journal of Poultry Science, 9(4): 309-316. DOI: https://www.doi.org /10.3923/ijps.2010.309.316

Lee MH (1995). Official methods of analysis of AOAC International (16th edn) Trends in Food Science \& Technology. Cunniff, AOAC International, DOI: https://www.doi.org /10.1016/0924-2244(95)90022-5

Li Y, Luo C, Wang J, and Guo F (2017). Effects of different raising systems on growth performance, carcass, and meat quality of medium-growing chickens. Journal of Applied Animal Research, 45(1): 326-330. DOI: https://www.doi.org/10.1080/09712119.2016.1190735. 
Lin CG, Kuo HY, and Wan TC (2014). Effect of free-range rearing on meat composition, physical properties and sensory evaluation in Taiwan game hens. AsianAustralasian Journal of Animal Sciences, 27(6): 880-885. Available at: http://www.ncbi.nlm.nih.gov/pmc/articles/PMC4093180/

Miele M (2011). The taste of happiness: Free-range chicken. Environment and Planning A: Economy and Space, 43(9): 2076-2090. DOI: https://www.doi.org/10.1068/a43257

Mikulski D, Celej J, Jankowski J, Majewska T, and Mikulska M (2011). Growth performance, carcass traits and meat quality of slower-growing and fast-growing chickens raised with and without outdoor access. Asian-Australas Journal of Animal Science, 24(10): 1407-1416. DOI: https://www.doi.org/10.5713/ajas.2011.11038

Połtowicz K, and Doktor J (2011). Effect of free-range raising on performance, carcass attributes and meat quality of broiler chickens. Animal Science Papers and Reports, 29(2): 139149. Available at: https://journals.indexcopernicus.com/search/article?articleId $=72754$

Ponte PIP, Rosado CMC, Crespo JP, Crespo DG, and Mourão JL (2008). Pasture intake improves the performance and meat sensory attributes of free-range broilers. Poultry Science, 87(1): 71-79. DOI:_http://www.dx.doi.org/10.3382/ps.200700147

Saleh EA, Ellakany HF, El-Far AH, Kadry S, and Elbestawy AR (2015). Meat quality and biochemical parameters related to human health under organic broiler production. Global Veterinaria, 14(3): 409-417. DOI: https://www.doi.org /10.5829/idosi.gv.2015.14.03.93115

Santos AL, Sakomura NK, Freitas ER, Fortes CMS, and Carrilho ENVM (2005). Comparison of free range broiler chicken strains raised in confined or semi-confined systems. Revista Brasileira de Ciência Avícola, 7: 85-92. Available at: http://www.scielo.br/scielo.php?script=sci_arttext\&pid=S15 16-635X2005000200004\&nrm=iso
Srednicka-Tober D, Baranski M, Seal C, Sanderson R, and Benbrook C (2016). Composition differences between organic and conventional meat: A systematic literature review and meta-analysis. British Journal of Nutrition, 115(6): 994-1011. DOI: https://www.doi.org /10.1017/S0007114515005073

Stadig LM, Rodenburg TB, Reubens B, Aerts J, and Duquenne B (2016). Effects of free-range access on production parameters and meat quality, composition and taste in slowgrowing broiler chickens. Poultry Science, 95(12): 29712978. DOI: https://www.doi.org /10.3382/ps/pew226

Tong HB, Wang Q, Lu J, Zou JM, and Chang LL (2014). Effect of free-range days on a local chicken breed: Growth performance, carcass yield, meat quality, and lymphoid organ index. Poultry Science, 93(8): 1883-1889. DOI: https://www.doi.org /10.3382/ps.2013-03470

Wang KH, Shi SR, Dou TC, and Sun HJ (2009). Effect of a freerange raising system on growth performance, carcass yield, and meat quality of slow-growing chicken. Poultry Science, 88(10): 2219-2223. DOI: https://www.doi.org /10.3382/ps.2008-00423

Wierbicki E, and Deatherage FE (1958). Water content of meats, determination of water-holding capacity of fresh meats. Journal of Agricultural and Food Chemistry, 6(5): 387-392. DOI: https://www.doi.org/10.1021/jf60087a011

Xing T, Gao F, Tume RK, Zhou G, and Xu X (2019). Stress effects on meat quality: A mechanistic perspective. Comprehensive Reviews in Food Science and Food Safety, 18(2): 380-401. Available at: https://onlinelibrary.wiley.com/doi/abs/10.1111/15414337.12417

Yeung RMW, and Morris J (2001). Consumer perception of food risk in chicken meat. Nutrition and Food Science, 31(6): 270-279.

DOI: 